Chronic Obstructive Pulmonary Diseases:

Journal of the COPD Foundation

Review

\title{
Intrapleural Gene Therapy for Alpha-1 Antitrypsin Deficiency-Related Lung Disease
}

Katie M. Stiles, $\mathrm{PhD}^{1 *}$ Dolan Sondhi, $\mathrm{PhD}^{1 *}$ Stephen M. Kaminsky, $\mathrm{PhD}^{1}$ Bishnu P. De, $\mathrm{PhD}^{1}$ Jonathan B. Rosenberg, $\mathrm{PhD}^{1}$ Ronald G. Crystal, $\mathrm{MD}^{1}$

\begin{abstract}
Alpha-1 antitrypsin deficiency (AATD) manifests primarily as early-onset emphysema caused by the destruction of the lung by neutrophil elastase due to low amounts of the serine protease inhibitor alpha- 1 antitrypsin (AAT). The current therapy involves weekly intravenous infusions of AAT-derived from pooled human plasma that is efficacious, yet costly. Gene therapy applications designed to provide constant levels of the AAT protein are currently under development. The challenge is for gene therapy to provide sufficient amounts of AAT to normalize the inhibitor level and anti-neutrophil elastase capacity in the lung. One strategy involves administration of an adeno-associated virus (AAV) gene therapy vector to the pleural space providing both local and systemic production of AAT to reach consistent therapeutic levels. This review focuses on the strategy, advantages, challenges, and updates for intrapleural administration of gene therapy vectors for the treatment of AATD.
\end{abstract}

Abbreviations: alpha-1 antitrypsin deficiency, AATD; alpha-1 antitrypsin, AAT; adeno-associated virus, AAV; serine protease inhibitor, SERPIN; epithelial lining fluid, ELF; Food and Drug Administration, FDA; nonhuman primate, NHP; investigational new drug, IND

Funding Support: Not applicable.

Date of Acceptance: January 15, 2018

Citation: Stiles KM, Sondhi D, Kaminsky SM, De BP, Rosenberg JB, Crystal RG. Intrapleural gene therapy for alpha- 1 antitrypsin deficiencyrelated lung disease. Chronic Obstr Pulm Dis. 2018;5(4):244-257. doi: https://doi.org/10.15326/jcopdf.5.4.2017.0160

1 Department of Genetic Medicine, Weill Cornell Medical College, New York, New York

* KMS and DS contributed equally to this review

\section{Address correspondence to:}

Katie M. Stiles, PhD or

Dolan Sondhi, PhD

Department of Genetic Medicine

Weill Cornell Medical College

1300 York Avenue, Box 164

New York, New York 10065

Phone: (646) 962-4363

Fax: (646) 962-0220

E-mail: geneticmedicine@med.cornell.edu

\section{Keywords:}

alpha-1 antitrypsin deficiency; gene therapy; adeno-asssociated virus vectors

\section{Introduction}

Alpha-1 antitrypsin deficiency (AATD) is an autosomal recessive disorder that affects $1 / 1500$ to $1 / 5000$ people of European ancestry. 1,2 In the United States, approximately 90,000 individuals are affected, with an additional 175,000 worldwide. ${ }^{1,3,4}$ The disease manifests primarily in the lung, presenting as earlyonset emphysema and a reduced lifespan. ${ }^{5-11}$ Smoking accelerates the lung destruction process. ${ }^{12-14}$ AATD can also present as other lung diseases including bronchiectasis and asthma, and a subset of individuals develop liver cirrhosis or rarely, hepatocellular carcinoma, panniculitis and vasculitic or autoimmune disorders. ${ }^{4,15-23}$ The emphysema associated with AATD is caused by the slow destruction of the lung parenchyma by unregulated neutrophil elastase, which is released by dying or activated neutrophils. ${ }^{5-7,24}$ 
AAT regulates neutrophil elastase and other proteases, including proteinase 3, a-defensins, and cathepsin $G$, and has been shown to have anti-inflammatory properties and the ability to modulate immune responses. ${ }^{25-34}$ AAT, a serine protease inhibitor (SERPIN), mainly acts in the lower respiratory tract to inhibit the action of these proteases. AAT deficiency results in an imbalance between the proteases and AAT in the lung leading to destruction of the lung matrix and damage to the alveolar structures. ${ }^{5-7,24,35}$

AAT is a $52 \mathrm{kDa}$ protein that is produced and secreted mainly from the liver into the plasma. AAT reaches the lung primarily by diffusion from the circulation, ${ }^{5-8,10,13,36-38}$ but a small amount is also produced locally by bronchial epithelial cells, mononuclear phagocytes, and neutrophils. ${ }^{39-43}$ The normal range of AAT in the serum is 20 to $53 \mu \mathrm{M}$; levels $>11 \mu \mathrm{M}$ are required to protect the lung from destruction. $4,7,13,44,45$ The low levels of AAT in AATD are caused by mutations in the SERPINA1 gene that has over 120 naturally occurring allelic variants. ${ }^{2,4,46-49}$ The normal $M$ alleles, consisting of M1(Ala213), M1(Val213), M2, M3, and M4, are present in more than $98 \%$ of the population. ${ }^{50}$ The most prevalent deficient allele is the $Z$ variant, which has a single amino acid substitution of lysine for glutamic acid at position 342 (E342K) that causes the polymerization of the AAT protein during posttranslational processing preventing its secretion from hepatocytes. 1,2,8,51-54 Homozygous Z individuals have $10 \%-15 \%$ of the serum AAT levels of individuals with the normal $M$ allele and account for $>95 \%$ of cases of clinically diagnosed AATD. ${ }^{2,5-7,13,16,38,55}$ The S allele, which has an amino acid substitution of valine for glutamic acid at position 264 (E264V), results in an AAT with reduced serum half-life due to instability of the protein. ${ }^{56-59}$ Homozygous $S$ individuals have $\sim 50 \%$ of normal AAT serum levels and are not at risk, but $15 \%$ to $20 \%$ of SZ heterozygotes have serum levels $<11 \mu \mathrm{M}$ and are at risk for disease development. ${ }^{60}$

The current therapeutic strategy to protect individuals with AATD from the development and progression of emphysema is to supplement the levels of plasma AAT above the level needed to prevent destruction by proteases. The susceptibility of the lung to destruction in the absence of AAT results from the significant portion of neutrophils that reside in the pulmonary capillaries leaving the lung at high risk from unchecked neutrophil elastase destruction. ${ }^{61}$
AAT is produced mainly in liver hepatocytes and circulates systemically, but as the predominant serine protease inhibitor, its main function is to protect the fragile alveolar structures of the lung from neutrophil elastase. The level of AAT required for protection was determined to be $11 \mu \mathrm{M}$ in the serum based on clinical observation of the development of emphysema in AATD patients. ${ }^{62}$ AAT reaches the lung by diffusion from the circulation, and the level in the lung interstitium is $\sim 50 \%$ of plasma levels. Further diffusion into the epithelial lining fluid (ELF) is limited by the tight junctions formed by the cells of the alveolar epithelium. The level of AAT in ELF is $\sim 5 \%$ to $10 \%$ of plasma levels, and the level required for protection is $1.2 \mu \mathrm{M} .{ }^{36,62}$ Thus, the rationale behind the current treatment strategy is to normalize levels of AAT in the ELF and interstitium by infusing AAT into the circulation and allowing it to diffuse to the other compartments, thereby normalizing the AAT levels. As long as the AAT in the plasma is above the protective threshold of $11 \mu \mathrm{M}$, the alveolar compartments should receive sufficient AAT to be protected. Based on this hypothesis, the current therapy consists of weekly intravenous infusions of $60 \mathrm{mg} / \mathrm{kg}$ of AAT purified from pooled human plasma to boost the level of circulating AAT. With this protein amount, AAT levels in serum are highly increased directly after the infusion but fall to near the protective threshold after one week due to the 4.5 day half-life of AAT. ${ }^{62}$ This therapeutic strategy was approved by the Food and Drug Administration (FDA) on the basis of its biochemical efficacy of maintaining the protective level of the AAT in the serum and the corresponding normalization of the AAT level and anti-neutrophil elastase capacity in the lungs. ${ }^{63}$ Clinical efficacy of this therapeutic strategy was demonstrated recently using computer tomography lung density scans at total lung capacity to validate the reduced rate of progression of lung destruction. ${ }^{64,65}$

\section{Gene Therapy for Alpha-1 Antitrypsin Deficiency}

Although AAT protein augmentation is effective at reestablishing AAT levels in plasma and lung ELF and in slowing the progression of the destructive lung disease caused by AATD, ${ }^{64,65}$ it is costly and requires weekly intravenous infusions of purified AAT from pooled human plasma. The necessary repetitive 
intravenous therapy derived from a human product presents problems of patient compliance and risks of allergic reactions, viral contamination, or limitations in available supply. ${ }^{66-68}$ Gene therapy to treat AATD has the possibility to alleviate all of these issues. The potential for a one-time administration reduces the burden on the patient of weekly time-consuming and invasive procedures and the associated issue of patient compliance. If effective, once gene therapy has been delivered, constant levels of AAT protein would be generated and released into the circulation, eliminating the current pattern of AAT peaks directly after infusion and AAT troughs by the end of the cycle. Thus, gene therapy offers a strategy that will persistently provide protective levels of AAT to the lung and has lower risk with fewer issues for patients and supply.

The current gene therapy strategies for AAT therapy involve delivering the normal human $M$ allele coding sequence under the control of a highly active constitutive promoter using a gene transfer vector (Figure 1). The goal is for transduced cells to secrete sufficient amounts of AAT into the circulation to normalize the levels of protective AAT in the lungs by diffusion after a single administration. Although a number of gene transfer vectors have been tested for delivery of the normal M-type AAT coding sequence in the past 25 years (reviewed in Chiuchiolo and Crystal $^{61}$ and Sondhi et $\mathrm{al}^{69}$ ), the adeno-associated virus (AAV) vectors are the delivery vehicles of choice. AAV is a small parvovirus that does not cause disease in humans and causes little toxicity upon administration at doses $<10^{15}$ genome copies. ${ }^{70,71} \mathrm{AAV}$ vectors are highly effective at transducing a broad range of organs in vivo and provide persistent expression of the protein when delivered to non-proliferating cells. ${ }^{70}$ There are 6 classically described human serotypes of AAV and greater than 50 recently identified serotypes from humans and nonhuman primates (NHPs). ${ }^{72,73}$ Many AAV serotypes are available for use that have low prevalence in the general population and low or absent levels of pre-existing anti-vector immunity. ${ }^{72,73}$ Serotypes AAV1, AAV2, AAV5, AAV6, AAV8, AAV9, and AAVrh.10 have all been used in preclinical studies of AAT therapy, ${ }^{74-88}$ and clinical studies have been carried out using AAV1 and AAV2 vectors. ${ }^{89-91}$

\title{
Figure 1. Design of an Adeno-Associated Virus Vector
}

\section{Expression cassette}

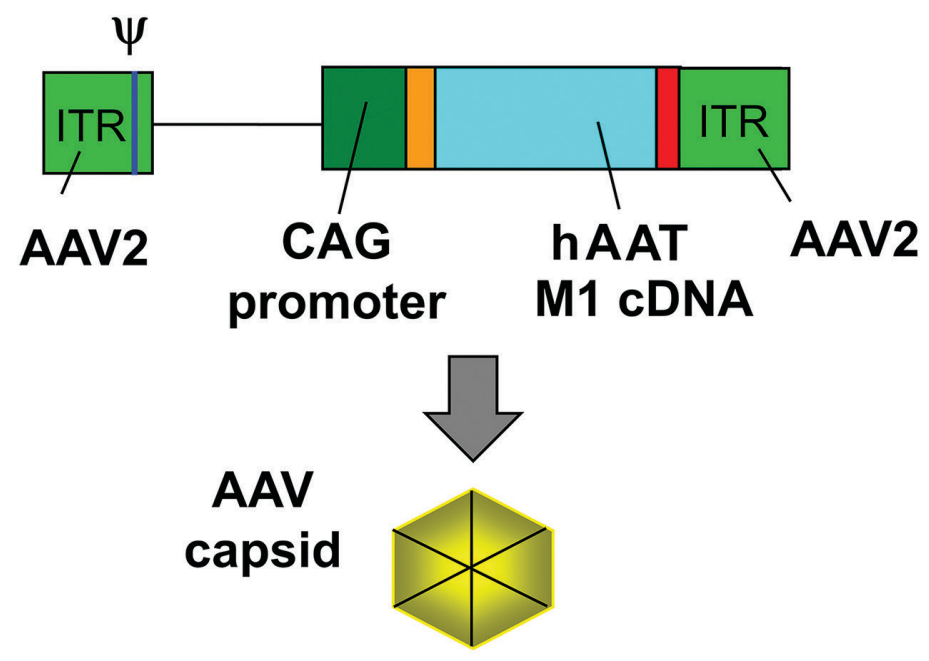

\begin{abstract}
Shown is the expression cassette with the coding sequence for the AAT M1 cDNA driven by the highly active, constitutive CAG promoter, followed by an intron, (orange) the AAT cDNA and the polyA (red) signal flanked by AAV2 inverted terminal repeats (ITR). The genome is packaged in an AAV capsid.
\end{abstract}

$\mathrm{AAV}=$ adeno-associated virus; ITR=inverted terminal repeats; hAAT=human alpha-1 antitrypsin 


\section{The Case for Intrapleural Administration for Alpha-1 Antitrypsin Gene Therapy}

Depending on the route of administration, the delivery of the AAT gene could allow AAT to be produced by many different cells and organs in addition to hepatocytes where the bulk of natural AAT is produced. This opens an array of possible routes of administration for a gene therapy vector, with the primary goal being to achieve the threshold levels of AAT protein of $11 \mu \mathrm{M}$ in the serum and $1.2 \mu \mathrm{M}$ in the alveolar ELF necessary to protect from neutrophil elastase proteolytic activity. ${ }^{7,13,36,62}$ Several different routes of administration have been attempted for AAT gene therapy. The earliest attempts targeted the respiratory tract epithelium directly, but the delivered vectors were unable to generate therapeutic levels of AAT. ${ }^{80,81,92,93}$ This failure is likely due to the natural defenses of the lung against pathogens and foreign substances, as well as the lack of viral receptors on the apical surface of respiratory epithelial cells. ${ }^{92-96}$ Routes of delivery that target the liver directly, including intravenous and intraportal administration, have been assessed in preclinical studies but have not made the transition into humans. ${ }^{76,85,87}$ Several studies have evaluated AAV vectors targeted to skeletal muscle in both preclinical animal studies and human clinical trials. ${ }^{75,79,84,97}$ A clinical trial utilizing AAV2 yielded very low expression of AAT. ${ }^{98}$ A trial with AAV1 met with more success as sustained expression of AAT was achieved, but the levels were much lower than the therapeutic threshold. ${ }^{89}$ In a second trial with AAV1, levels of $\sim 2 \%$ of the therapeutic level were sustained as long as 5 years. ${ }^{90,91}$

While each of these strategies target generally a single organ for vector transduction and AAT expression, intrapleural administration allows for both targeting of the lung directly and systemic delivery of the AAV gene transfer vector. The pleura is a thin serous membrane that encloses the chest cavity attaching the chest wall (parietal pleura) to the lung parenchyma (visceral pleura) ${ }^{99,100}$ (Figure 2A). Both the parietal and visceral pleura contain a single layer of mesothelial cells surrounded by a thin layer of connective tissue rich in lymphatic and blood vessels that are connected to the systemic circulation. The pleura layers are separated by a pleural fluid (0.5 to 1 $\mathrm{ml}$ in humans). ${ }^{100-105}$ Intrapleural gene transfer vector delivery has the benefits of both local lung delivery by transduction of the mesothelial cells lining the pleura and systemic delivery from vector passing through open stomata in the visceral pleural lymphatics to the systemic circulation and then primarily to liver hepatocytes (Figure 2B). AAT produced by the mesothelial cells is secreted and diffuses into the lung parenchyma. Because the lymphatic system of the parietal pleura connects directly from the pleural space through stomata, this allows for parallel systemic distribution of the gene therapy vector to primarily the liver via the circulation. ${ }^{99,100,106}$ AAT produced in the liver can travel back to the lung through the circulatory system. The major advantage of intrapleural administration is that both the lung and liver are targeted by the gene therapy vector, increasing the possibility of producing a sufficient amount of AAT to provide a therapeutic effect (Figure $2 \mathrm{C}$ ).

\section{Preclinical Efficacy of Intrapleural Administration of AAV Vectors}

In a mouse preclinical model, De et al ${ }^{77}$ demonstrated that an AAV serotype 5-based vector expressing the human AAT gene produced higher levels of serum AAT via the intrapleural route of delivery compared to intramuscular administration at the same dose. Moreover, the AAV5-based vector produced about 8 -fold higher levels of AAT compared to the levels achieved by an AAV2-based vector via both the intramuscular and intrapleural route. Intrapleural delivery of AAV5 coding for human AAT (administered dose of $10^{11} \mathrm{gc}$ ) mediated AAT serum levels of $900 \pm 50 \mu \mathrm{g} / \mathrm{ml}$ that were sustained up to 40 weeks postadministration. This level is significantly greater (1.6fold) than the therapeutic threshold level of $570 \mu \mathrm{g} /$ $\mathrm{ml}(11 \mu \mathrm{M})$. The AAT levels in the bronchoalveolar lavage fluid were similar to that in serum, indicating local production of AAT in the lungs. ${ }^{77}$ These observations lend support to the concept that AAV5mediated intrapleural delivery of the AAT transgene can provide sufficient amounts of AAT to be able to protect the lung from proteolytic damage.

To identify a more potent AAV serotype than AAV5, De et al ${ }^{78}$ compared 25 different AAV serotypes (16 NHPs and 9 human AAV serotypes; all using the AAV2 inverted terminal repeats flanking the same human AAT CDNA driven by the CAG promoter) in mice (Figure 1). The authors demonstrated that intrapleural 


\section{Figure 2. Intrapleural Administration of an Adeno-Associated Virus Vector Coding for Alpha-1 Antitrypsin}

\section{A. Anatomy of the human pleura}

\section{Intrapleural vector}

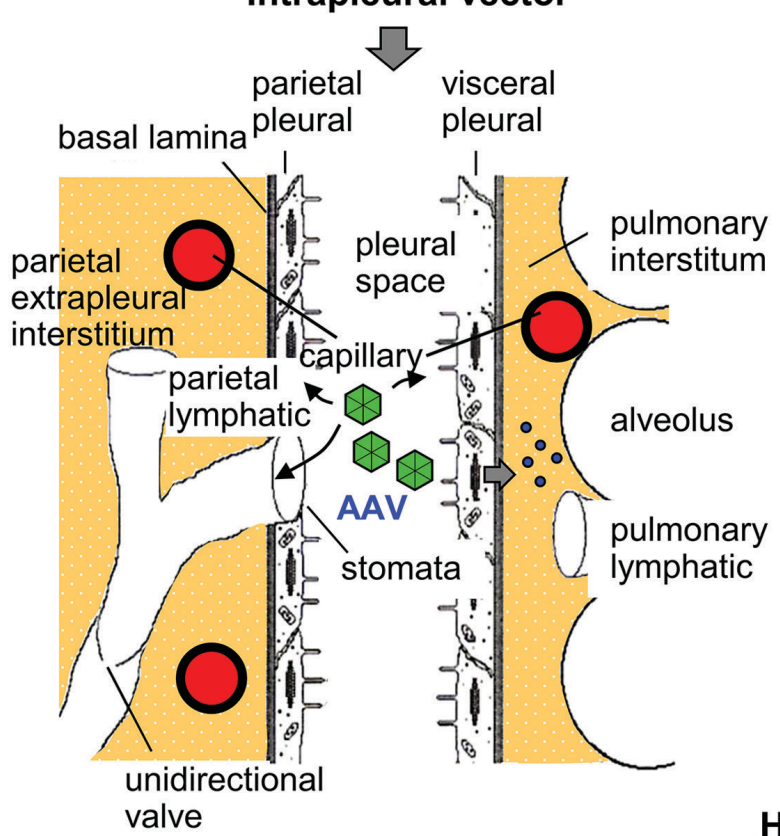

\section{B. Vector distribution following intrapleural administration}

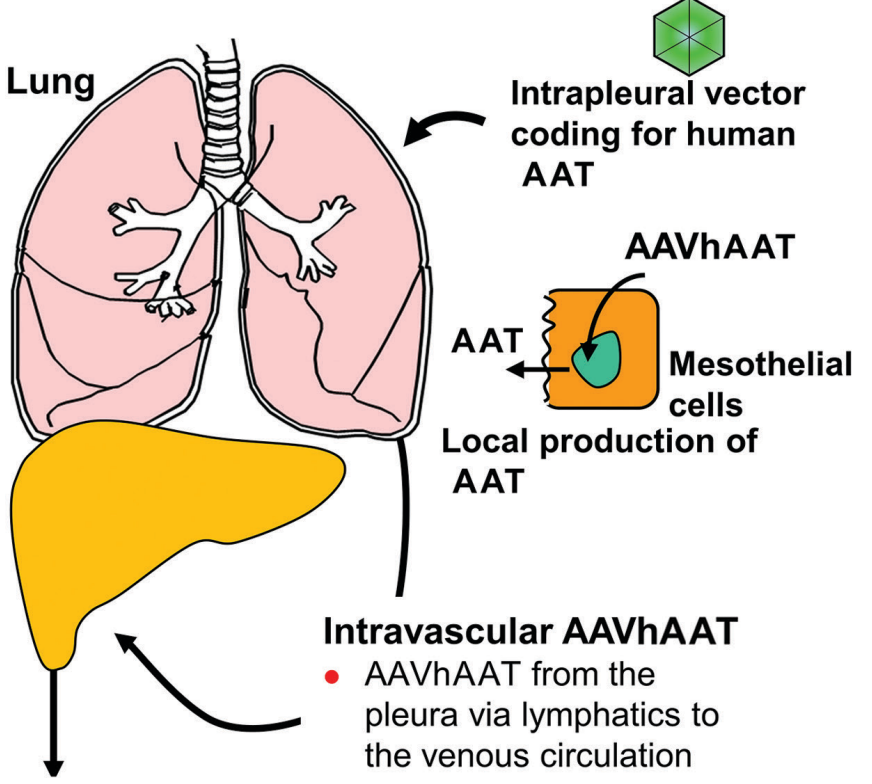

Hepatocyte expression of AAT

- AAT secreted into blood diffuses across the alveoli

\section{Distribution of vector-generated AAT in the alveoli}

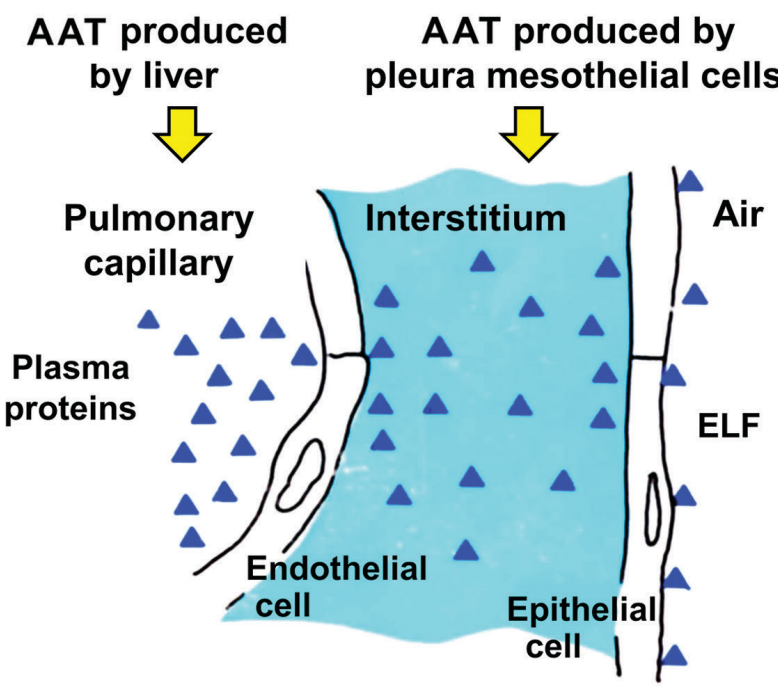

A. Anatomy of the lung pleura. B. Vector distribution following intrapleural administration, combining local lung delivery via vector transduction of mesothelial cells lining the pleura, and systemic delivery via vector leaking to the systemic venous system and then primarily to liver hepatocytes. C. Delivery to the alveoli of AAT produced by AAV gene therapy to the pleura. The endothelial junctions are relatively loose, such that the levels of AAT (MW $52 \mathrm{kDa}$ ) in the interstitium are $60 \%$ of that in plasma. The epithelial junctions are tight, resulting in ELF AAT levels 5\% to $10 \%$ of plasma. The locally (mesothelial cell) expressed AAT is delivered directly to the alveolar interstitium, while the liver (hepatocyte) expressed AAT diffuses from plasma to the interstitium, and then to alveolar ELF. 
administration of the AAV nonhuman primate derived serotypes AAVrh.10 and AAV8 (both clade E) were the most effective at providing high serum AAT levels. Of the other serotypes tested, 11 were derived from rhesus macaques (AAV7, AAVrh.2, AAVrh.8, AAVrh.13, AAVrh.16, AAVrh.20, AAVrh.21, AAVrh.22, AAVrh.24, AAVrh.34 and AAVrh.43), and 1 was derived from cynomolgus macaque (AAVcy.5), 1 from baboon (AAVbb.2), 1 from chimpanzee (AAVch.5); and 9 from humans (AAV2, AAV5, AAV9, AAVhu.1, AAVhu.11, AAVhu.13, AAVhu.37, AAVhu.41, and AAVhu.47). The AAVrh.10 vector was chosen for further study. Administration of the AAVrh.10 vector $\left(10^{11} \mathrm{gc}\right)$ via the intrapleural route in the left lung resulted in high levels of transgene expression in the lungs, diaphragm, and liver (Figure 3). Additionally, this route of administration with AAVrh.10 produced sustained therapeutic levels of serum AAT ( $>2.5$-fold above the minimum of $570 \mu \mathrm{g} / \mathrm{ml}$, compared to the 1.6-fold levels produced by AAV5) up to 24 weeks, the latest point of the study (Figure 4A). The high serum AAT levels translated to similar therapeutic levels in lung ELF, demonstrating biochemical efficacy (Figure 4B). Importantly, the AAVrh.10 vector-produced AAT was functional in the inhibition of neutrophil elastase. In the context that AAV vectors are less potent in female mice, administration of AAVrh. 10 vector $\left(10^{11} \mathrm{gc}\right)$ via the intrapleural route produced greater than therapeutic levels of AAT not just in male mice but also in female mice. The AAVrh.10 vector is derived from rhesus macaque, and therefore, another potential advantage is that pre-existing anti-vector immunity in humans is minimal. ${ }^{107}$ To assess whether the AAVrh.10 vector is functional in the presence of pre-existing immunity against the common human serotypes AAV2 and AAV5, administration of the AAVrh.10hAAT to AAV2- and AAV5-preimmune mice showed high level expression of AAT compared to nonimmune mice, thus demonstrating that AAVrh.10 is capable of circumventing common human immunity to AAV. ${ }^{78}$

\section{AAVrh.10hAAT Safety and Toxicology Study}

Based on the promising efficacy data with AAVrh.10hAAT in mice, the novel intrapleural delivery approach advanced to a safety and toxicology study. ${ }^{74}$ This study included 280 mice and 36 NHPs.
The AAVrh.10 vector was administered via the intrapleural route at 2 doses in each species $\left(10^{10}\right.$ and $10^{11} \mathrm{gc}$ in mice, $10^{12}$ and $10^{13} \mathrm{gc}$ in NHPs). The safety of the intrapleural vector delivery assessment parameters included hematology, serum chemistry and histopathology. Additionally, vector genome biodistribution and transgene expression were evaluated at multiple time points over 6 months.

The mouse toxicology study involved 2 parts. For the primary study, 120 male and 120 female mice were administered either PBS or AAVrh.10hAAT $\left(10^{10} \mathrm{gc}\right.$ or $\left.10^{11} \mathrm{gc}\right)$ by the intrapleural route, with assessment of: (1) safety following vector intrapleural administration; (2) biodistribution of the vector; and (3) hAAT mRNA expression in chest cavity organs over a course of 6 months. The second study assessed the potential toxicity of direct injection of PBS (control) or $10^{11}$ gc AAVrh.10hAAT into lung parenchyma in 20 male and 20 female mice, as a worse case scenario model for misplaced dosing during intrapleural administration over the course of a month. Overall, the AAVrh.10hAAT vector was well tolerated without any vector-related morbidity or mortality in either group, except a few surgical procedure-related deaths in the group receiving vector via intrapleural administration ( $n=8$ of 240 ). For both studies, the assessment of hematology, serum chemistry and histopathology showed the therapy to be safe. In the intrapleural study, all of the vector-administered groups of mice developed dose-dependent AAVrh.10 neutralizing antibodies. Assessment of vector DNA in various organs showed high levels of transduction of the liver $\left(>10^{6}\right.$ copies/ $\mu \mathrm{g}$ total DNA at the high dose and $>10^{4}$ copies/ $\mathrm{ug}$ total DNA at the low dose) followed by the diaphragm and lungs, while other organs had low vector DNA levels, detectable only in the higher dose group. To assess whether intrapleural delivery of the vector mediated sufficient transgene expression in the chest cavity, AAT mRNA levels were quantified in chest cavity organs. The diaphragm had the highest levels of mRNA ( $>10^{6}$ copies/ug total RNA at the high dose and $>10^{4}$ copies/ $\mu$ g total RNA at the low dose), and these levels were sustained up to 182 days, the latest time point of the study. Similar high levels of AAT mRNA were detectable in other chest cavity organs including pleura, left lung and right lung, demonstrating efficient transgene delivery to the proximity of the lung and hence availability to protect the lung from proteolytic damage. 


\section{Figure 3. Transgene Expression Organ Distribution After Adeno-Associated Virus Vector rh.10 Intrapleural Administration}
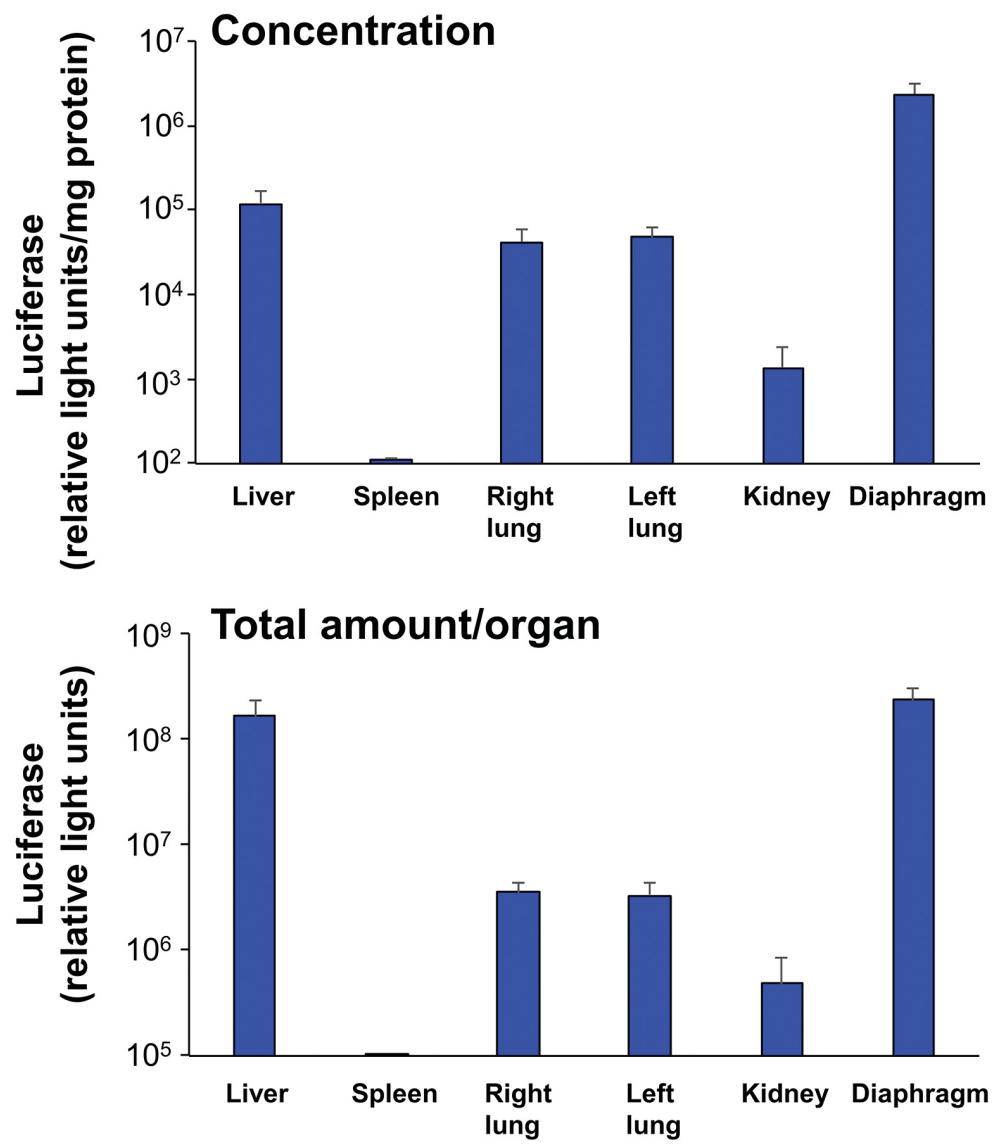

The distribution of luciferase expressed from an AAVrh.10 vector administered by intrapleural administration was assessed in various organs. The luciferase activity/ mg protein (upper panel) and total amount per organ (lower panel) are shown.

AAV=adeno-associated virus

The NHP study included 18 male and 18 female African green monkeys. Overall safety and vectormediated expression of AAT in the chest cavity was assessed. All animals remained healthy with normal weight gain, heart rate and respiratory rate. Overall hematology parameters and serum chemistry data were normal, with only a few sporadic changes in individual animals that were not statistically significant. Pathology and organ weights measured at necropsy showed that there were no vector-related gross anatomic changes and organ-to-body and organ-to-brain weights remained normal. No vectorrelated significant histopathological changes were observed. Assessment of AAVrh.10 neutralizing antibody levels in serum showed dose-dependent AAVrh.10 neutralizing antibody titers, persisting up to 360 days, the latest time point of the study. Finally, quantification of human AAT mRNA in the chest cavity tissues demonstrated high levels of human AAT mRNA localized to the proximity of the lung with the mRNA levels persisting up to 360 days at $>10^{4}$ copies/ug total RNA in chest wall pleura, diaphragm, and diaphragm pleura.

The combined data from these pivotal toxicology studies in 2 species (mice and NHPs) demonstrated that the approach of delivering AAVrh.10hAAT by the intrapleural route is both efficient and safe with no toxicity issues. This study provided the groundwork for the planned initiation of a clinical trial of intrapleural human AAVrh.10hAAT for the treatment of AAT deficiency. 


\section{Figure 4. Intrapleural Administration of Adeno-Associated Virus Vector Coding for Human Alpha-1 Antitrypsin}

\section{A. Time course in serum}

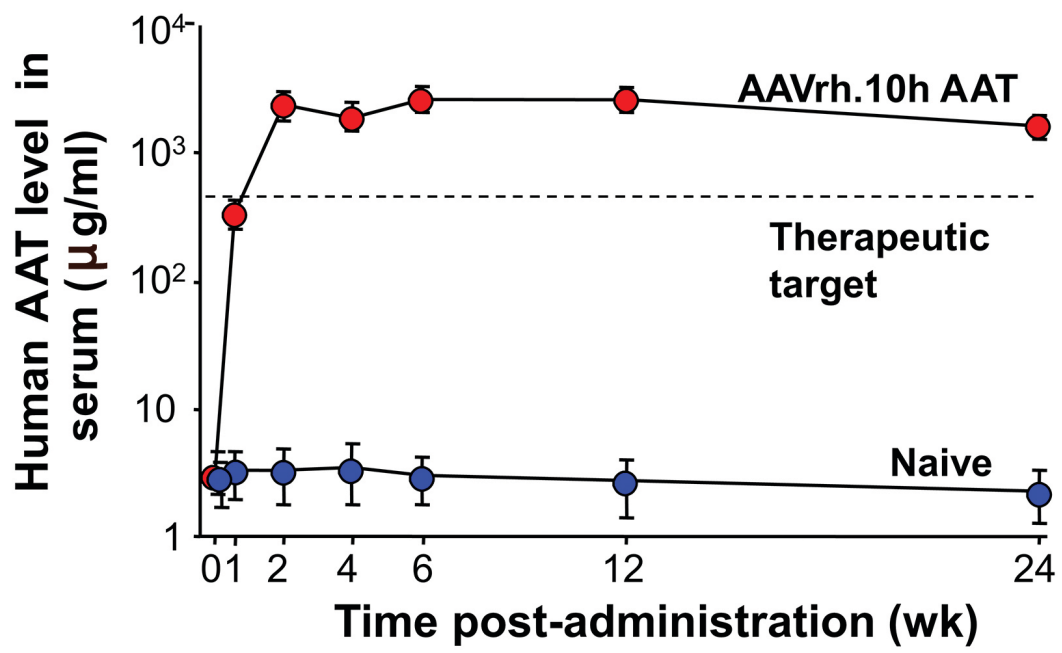

B. Comparison of lung (lavage) and serum human AAT levels

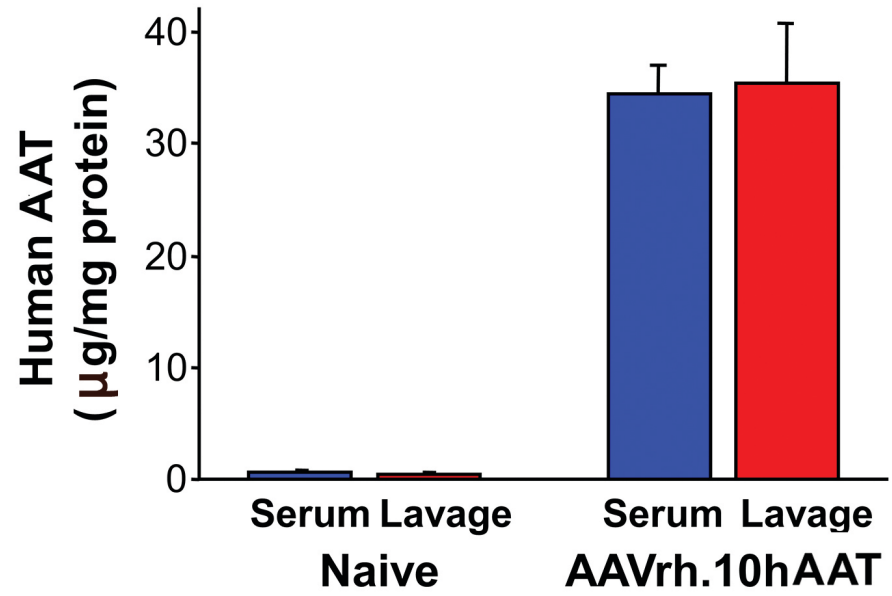

\footnotetext{
A. Persistent AAT levels in serum after AAVrh.10hAAT intrapleural administration ( $\left.10^{11} \mathrm{gc}\right) \mathrm{male} \mathrm{C} 57 \mathrm{~B} 1 / 6 \mathrm{mice}$ ( $\left.\mathrm{n}=4 / \mathrm{group}\right)$. Serum human AAT levels were assayed by ELISA. B. Human AAT levels in bronchoalveolar lavage fluid compared to serum at 8 wk after intrapleural administration of $10^{11} \mathrm{gc} \mathrm{AAVrh.10h}$ AAT (C57Bl/ 6 mice, n=4).
}

\section{Design of the Clinical Trial}

On the basis of the above described efficacy and safety/ toxicology studies of intrapleural administration of a serotype rh.10 replication-deficient AAV gene transfer vector expressing the human AAT cDNA in mice and in NHPs, an investigational new drug (IND) application was submitted to the FDA. This IND has been granted by the FDA (BBIND 16008) and has been licensed to Adverum Biotechnologies. The allowed clinical study (Protocol No. 1401014659, Clinical Trial ID: NCT02168686) is a gene transfer strategy designed to provide persistent high levels of human AAT. The study design has been previously published ${ }^{108}$ and is 
summarized here.

This study is designed as a phase I/II clinical trial to assess the safety and determine the preliminary efficacy of AAVrh.10hAAT (expressing the normal M1-type AAT) in humans with AATD. It is a 2-dose, open label study with $\mathrm{n}=5$ individuals in each dose cohort $\left(8 \times 10^{12}\right.$ and $\left.8 \times 10^{13} \mathrm{gc}\right)$ receiving the vector by the intrapleural delivery route. In addition, as a comparison to the intrapleural route, $n=5$ AATdeficient individuals at each dose level will instead be administered the AAVrh.10h AAT vector by the intravenous route. $A$ total of $n=20$ individuals with a genotype of ZZ or Z Null, with serum AAT levels of $<11 \mu \mathrm{M}$ will be recruited to participate in this study. All participants will be monitored before and after vector administration with a variety of safety measures. In addition, biologic efficacy parameters will be assessed to generate preliminary assessment of the therapeutic impact of this intervention including serum and ELF AAT levels and function. The goal for the treatment to be considered efficacious and therapeutic is for the serum AAT levels to be $>11 \mu \mathrm{M}$ and AAT levels in the lung ELF to be $>1.2 \mu \mathrm{M}$, the levels considered to be the "protective level" for AAT. 63

\section{Intrapleural AAT Gene Therapy- Moving Forward}

Information gleaned from previous AAT clinical trials combined with the data from the preclinical studies suggest that intrapleural delivery of an AAVrh.10hAAT is a promising treatment for AATD. The upcoming clinical trials will help to determine whether administration of this vector by the intrapleural route will finally allow gene therapy to achieve the target protective level for biochemical efficacy. Achieving this primary end goal still opens the door for further questions to be evaluated. The next step after a demonstration of biochemical efficacy would be to evaluate clinical efficacy by monitoring stabilization of lung function or employing computer tomography lung density scans at total lung capacity to evaluate the rate of progression of lung destruction, as recently shown for AAT protein supplementation therapy. ${ }^{64,65}$ The advantage of AAT gene therapy over the current protein supplementation therapy is the potential for a single administration of the treatment. AAV vectors have been shown to drive persistent AAT expression out to at least 5 years with little diminution in the level of expression. ${ }^{90,91}$ However, the total longevity of expression is not yet known, and this leaves the possibility that readministration of the AAT gene therapy may be necessary during the lifetime of the patient. Future studies would be needed to help determine if an alteration in AAV serotype or the use of an immunodepressant regimen might be required for readministration or whether additional enhancements to current vectors might further improve gene expression stability.

\section{Acknowledgements}

We thank N. Mohamed for help in preparing the manuscript.

\section{Declaraton of Interest}

Adverum Biotechnologies has licensed the AAVrh.10hAAT intrapleural technology and investigational new drug from Cornell University. RGC is a consultant and holds equity in Adverum. RGC, DS, SK share licensing fees paid to Cornell University. 


\section{References}

1. Blanco I, Bueno P, Diego I, et al. Alpha-1 antitrypsin Pi*Z gene frequency and $\mathrm{Pi}^{*} \mathrm{ZZ}$ genotype numbers worldwide:an update. Int J Chron Obstruct Pulmon Dis. 2017;12:561-569.

2. de Serres FJ, Blanco I. Prevalence of alpha 1-antitrypsin deficiency alleles $\mathrm{PI}^{*} \mathrm{~S}$ and $\mathrm{PI} Z \mathrm{Z}$ worldwide and effective screening for each of the five phenotypic classes $\mathrm{PI}^{*} \mathrm{MS}, \mathrm{PI}^{*} \mathrm{MZ}, \mathrm{PI}^{*} \mathrm{SS}, \mathrm{PI}^{*} \mathrm{SZ}$, and PI*ZZ:a comprehensive review. Ther Adv Respir Dis. 2012;6:277295. doi: https://doi.org/10.1177/1753465812457113

3. Luisetti M, Seersholm N. Alpha1-antitrypsin deficiency. 1:epidemiology of alpha1-antitrypsin deficiency. Thorax. 2004;59(2):164-169.

doi: https://doi.org/10.1136/thorax.2003.006494

4. Stoller JK, Aboussouan LS. A review of alpha1-antitrypsin deficiency. Am J Respir Crit Care Med. 2012;185(3):246-259. doi: https://doi.org/10.1164/rccm.201108-1428CI

5. Brantly M, Nukiwa T, Crystal RG.) Molecular basis of alpha-1antitrypsin deficiency. Am J Med. 1988;84(Supp 6):13-31. doi: https://doi.org/10.1016/S0002-9343(88)80066-4

6. Brantly ML, Paul LD, Miller BH, et al. Clinical features and history of the destructive lung disease associated with alpha1-antitrypsin deficiency of adults with pulmonary symptoms. 1988. Am Rev Respir Dis. 138(2):327-336.

doi: https://doi.org/10.1164/ajrccm/138.2.327

7. Crystal RG. Alpha 1-antitrypsin deficiency, emphysema, and liver disease. Genetic basis and strategies for therapy. J Clin Invest. 1990;85:1343-1352. doi: https://doi.org/10.1172/JCI114578

8. Lomas DA, Parfrey H. Alpha 1-antitrypsin deficiency. 4:Molecular pathophysiology. Thorax. 2004;59(6):529-535. doi: https://doi.org/10.1136/thx.2003.006528

9. Tanash HA, Nilsson PM, Nilsson JA, Piitulainen E. Survival in severe alpha-1-antitrypsin deficiency (PiZZ). Respir Res. 2010;11:44. doi: https://doi.org/10.1186/1465-9921-11-44

10. Tuder RM, Janciauskiene SM, Petrache I. Lung disease associated with alpha1-antitrypsin deficiency. Proc Am Thorac Soc. 2010;7(6):381-386.

doi: https://doi.org/10.1513/pats.201002-020AW

11. The Alpha-1-Antitrypsin Deficiency Registry Study Group. Survival and FEV1 decline in individuals with severe deficiency of alpha1-antitrypsin. Am J Respir Crit Care Med. 1998; 158(1):49-59.

12. Alam S, Li Z, Janciauskiene S, Mahadeva R. Oxidation of Z alpha 1-antitrypsin by cigarette smoke induces polymerization:a novel mechanism of early-onset emphysema. Am J Respir Cell Mol Biol. 2011;45(2):261-269.

doi: https://doi.org/10.1165/rcmb.2010-03280C
13. Crystal RG, Brantly ML, Hubbard RC, Curiel DT, States DJ, Holmes MD. The alpha 1-antitrypsin gene and its mutations. Clinical consequences and strategies for therapy. Chest. 1989;95(1):196-208. doi: https://doi.org/10.1378/chest.95.1.196

14. Lockett AD, Van Demark M, Gu Y, et al. Effect of cigarette smoke exposure and structural modifications on the alpha-1 antitrypsin interaction with caspases. Mol Med. 2012.18:445-454. doi: https://doi.org/10.2119/molmed.2011.00207

15. Alberici F, Martorana D, Vaglio A (2014) Genetic aspects of antineutrophil cytoplasmic antibody-associated vasculitis. Nephrol Dial Transplant. 2014;30 (Suppl 1):i37-i45. doi: https://doi.org/10.1093/ndt/gfu386

16. de Serres F, Blanco I. Role of alpha-1 antitrypsin in human health and disease. J Intern Med. 2014;276(4):311-335. doi: https://doi.org/10.1111/joim.12239

17. Duvoix A, Roussel BD, Lomas DA. Molecular pathogenesis of alpha-1-antitrypsin deficiency. Rev Mal Respir. 2014;31(10):9921002. doi: https://doi.org/10.1016/j.rmr.2014.03.015

18. Eden E, Mitchell D, Mehlman B, et al. Atopy, asthma, and emphysema in patients with severe alpha-1-antitrypysin deficiency. Am J Respir Crit Care Med. 1997;156(1):68-74. doi: https://doi.org/10.1164/ajrccm.156.1.9508014

19. Inaty H, Arabelovic S. Alpha1-antitrypsin deficiency in a patient diagnosed with granulomatosis with polyangiitis. BMJ Case Rep. 2013. doi: https://doi.org/10.1136/bcr-2013-009045

20. Perlmutter DH, Silverman GA. Hepatic fibrosis and carcinogenesis in alpha1-antitrypsin deficiency:a prototype for chronic tissue damage in gain-of-function disorders. Cold Spring Harb Perspect Biol 3. 2011;3(3):a005801. doi: https://doi.org/10.1101/cshperspect.a005801

21. Stone H, Pye A, Stockley RA. Disease associations in alpha-1antitrypsin deficiency. Respir Med. 2014;108(2):338-343. doi: https://doi.org/10.1016/j.rmed.2013.10.006

22. Teckman JH. Liver disease in alpha-1 antitrypsin deficiency:current understanding and future therapy. COPD. 2013;10(Suppl 1):35-43.

doi: https://doi.org/10.3109/15412555.2013.765839

23. Topic A, Radojkovic D. Polymerization and oxidation of alpha-1antitrypsin in pathogenesis of emphysema. In:Irusen E, ed. Lung Diseases-Selected State of the Art Reviews. London:IntechOpen Limited;2012. http://www.intechopen.com/books/lung-diseases -selected-state-of-the-art-reviews/polymerization-and-oxidationof-alpha-1-antitrypsin-in-pathogenesis-of-emphysema. Accessed January 2018.

24. Guyot N, Wartelle J, Malleret L, et al. Unopposed cathepsin G, neutrophil elastase, and proteinase 3 cause severe lung damage and emphysema. Am J Pathol. 2014;184(8):2197-2100. doi: https://doi.org/10.1016/j.ajpath.2014.04.015 
25. Bergin DA, Reeves EP, Hurley K, et al. The circulating proteinase inhibitor alpha-1 antitrypsin regulates neutrophil degranulation and autoimmunity. Sci Transl Med. 2014;6(217).

doi: https://doi.org/10.1126/scitranslmed.3007116

26. Duranton J, Bieth JG (2003) Inhibition of proteinase 3 by [alpha]1-antitrypsin in vitro predicts very fast inhibition in vivo. Am J Respir Cell Mol Biol. 2003;29(1):57-61.

doi: https://doi.org/10.1165/rcmb.2002-0258OC

27. Geraghty P, Eden E, Pillai M, Campos M, McElvaney NG, Foronjy RF. Alpha1-antitrypsin activates protein phosphatase $2 \mathrm{~A}$ to counter lung inflammatory responses. Am J Respir Crit Care Med. 2014;190(11):1229-1242.

doi: https://doi.org/10.1164/rccm.201405-0872OC

28. Janciauskiene SM, Nita IM, Stevens T. Alpha1-antitrypsin, old dog, new tricks. Alpha1-antitrypsin exerts in vitro antiinflammatory activity in human monocytes by elevating cAMP. J Biol Chem. 2007;282:8573-8582.

doi: https://doi.org/10.1074/jbc.M607976200

29. Jonigk D, Al-Omari M, Maegel L, et al. Anti-inflammatory and immunomodulatory properties of alpha1-antitrypsin without inhibition of elastase. Proc Natl Acad Sci USA. 2013;110(37):15007-15012.

doi: https://doi.org/10.1073/pnas.1309648110

30. Kaner Z, Ochayon DE, Shahaf G, et al. Acute phase protein alpha1-antitrypsin reduces the bacterial burden in mice by selective modulation of innate cell responses. J Infect Dis. 2015; 211(9):1489-1498. doi: https://doi.org/10.1093/infdis/jiu620

31. Lewis EC. Expanding the clinical indications for alpha(1)antitrypsin therapy. Mol Med. 2012;18:957-970.

doi: https://doi.org/10.2119/molmed.2011.00196

32. Petrache I, Fijalkowska I, Medler TR, et al. A-1 antitrypsin inhibits caspase-3 activity, preventing lung endothelial cell apoptosis. Am J Pathol. 2006;169(4):1155-1166. doi: https://doi.org/10.2353/ajpath.2006.060058

33. Shahaf G, Moser H, Ozeri E, Mizrahi M, Abecassis A, Lewis EC. Alpha-1-antitrypsin gene delivery reduces inflammation, increases T-regulatory cell population size and prevents islet allograft rejection. Mol Med. 2011;17:1000-1011. doi: https://doi. org/10.2119/molmed.2011.00145

34. Spencer LT, Paone G, Krein PM, Rouhani FN, Rivera-Nieves J, Brantly ML. Role of human neutrophil peptides in lung inflammation associated with alpha1-antitrypsin deficiency. Am J Physiol Lung Cell Mol Physiol. 2004;286:L514-L520. doi: https://doi.org/10.1152/ajplung.00099.2003

35. Sinden NJ, Baker MJ, Smith DJ, Kreft JU, Dafforn TR, Stockley RA. Alpha-1-antitrypsin variants and the proteinase/ antiproteinase imbalance in chronic obstructive pulmonary disease. Am J Physiol Lung Cell Mol Physiol. 2015;308:L 179-L190. doi: https://doi.org/10.1152/ajplung.00179.2014
36. Gadek JE, Fells GA, Zimmerman RL, Rennard SI, Crystal RG. Antielastases of the human alveolar structures. Implications for the protease-antiprotease theory of emphysema. J Clin Invest. 1981;68:889-898. doi: https://doi.org/10.1172/JCI110344

37. Greene CM, Miller SD, Carroll T, et al. Alpha-1 antitrypsin deficiency:a conformational disease associated with lung and liver manifestations. J Inherit Metab Dis. 2008;31(1):21-34. doi: https://doi.org/10.1007/s10545-007-0748-y

38. Silverman EK, Sandhaus RA. Clinical practice. Alpha1antitrypsin deficiency. $N$ Engl J Med. 2009;360:2749-2757. doi: https://doi.org/10.1056/NEJMcp0900449

39. Cichy J, Potempa J, Travis J. Biosynthesis of alpha1-proteinase inhibitor by human lung-derived epithelial cells. J Biol Chem. 1997;272(13):8250-8255. doi: https://doi.org/10.1074/jbc.272.13.8250

40. du Bois RM, Bernaudin JF, Paakko P, et al. Human neutrophils express the alpha 1-antitrypsin gene and produce alpha 1-antitrypsin. Blood. 1991;77:2724-2730.

41. Mornex JF, Chytil-Weir A, Martinet Y, Courtney M, LeCocq JP, Crystal RG. Expression of the alpha-1-antitrypsin gene in mononuclear phagocytes of normal and alpha-1-antitrypsindeficient individuals. J Clin Invest. 1986;77:1952-1961. doi: https://doi.org/10.1172/JCI112524

42. van 't Wout EF, van Schadewijk A, Savage ND, Stolk J, Hiemstra PS. Alpha1-antitrypsin production by proinflammatory and antiinflammatory macrophages and dendritic cells. Am J Respir Cell Mol Biol. 2012;46:365-376.

43. Venembre P, Boutten A, Seta N, et al. Secretion of alpha 1-antitrypsin by alveolar epithelial cells. FEBS Lett. 1994;346:171174. doi: https://doi.org/10.1074/jbc.272.13.8250

44. Crystal RG. The alpha 1-antitrypsin gene and its deficiency states. Trends Genet. 1989;5:411-417.

doi: https://doi.org/10.1016/0168-9525(89)90200-X

45. Loring HS, Flotte TR. Current status of gene therapy for alpha-1 antitrypsin deficiency. Expert Opin Biol Ther. 2015;15(3):329336. doi: https://doi.org/10.1517/14712598.2015.978854

46. Cox DW, Markovic VD, Teshima IE Genes for immunoglobulin heavy chains and for alpha 1-antitrypsin are localized to specific regions of chromosome 14q. Nature. 1982;297:428-430. doi: https://doi.org/10.1038/297428a0

47. Laurell C-B, Eriksson S. The electrophoretic alpha1-globulin pattern of serum in alpha1-antitrypsin deficiency. Scand J Clin Lab Invest. 1963;15(2):132-140. doi: https://doi.org/10.1080/00365516309051324

48. Schroeder WT, Miller MF, Woo SL, Saunders GF. Chromosomal localization of the human alpha 1-antitrypsin gene (PI) to 14q3132. Am J Hum Genet. 1985;37(5):868-872. 
49. Seixas S, Garcia O, Trovoada MJ, Santos MT, Amorim A, Rocha J. Patterns of haplotype diversity within the serpin gene cluster at 14q32.1:insights into the natural history of the alpha1antitrypsin polymorphism. Hum Genet. 2001;108(1):20-30. doi: https://doi.org/10.1007/s004390000434

50. Kurachi K, Chandra T, Degen SJ, et al. Cloning and sequence of cDNA coding for alpha 1-antitrypsin. Proc Natl Acad Sci USA. 1981;78:6826-6830. doi: https://doi.org/10.1073/pnas.78.11.6826

51. Birrer P, McElvaney NG, Chang-Stroman LM, Crystal RG. Alpha 1-antitrypsin deficiency and liver disease. J Inherit Metab Dis. 1991;14(4):512-525. doi: https://doi.org/10.1007/BF01797921

52. Gooptu B, Lomas DA. Conformational pathology of the serpins:themes, variations, and therapeutic strategies. Annu Rev Biochem. 2009;78:147-176.

doi: https://doi.org/10.1146/annurev.biochem.78.082107.133320

53. Jeppsson JO (1976) Amino acid substitution Glu leads to Lys alpha1-antitrypsin PiZ. FEBS Lett. 1976;65(2):195-197. doi: https://doi.org/10.1016/0014-5793(76)80478-4

54. Lomas DA, Evans DL, Finch JT, Carrell RW. The mechanism of $\mathrm{Z}$ alpha 1-antitrypsin accumulation in the liver. Nature. 1992;357:605-607. doi: https://doi.org/10.1038/357605a0

55. Bornhorst JA, Greene DN, Ashwood ER, Grenache DG. Alpha1-Antitrypsin phenotypes and associated serum protein concentrations in a large clinical population. Chest. 2013;143(4):1000-1008.

doi: https://doi.org/10.1378/chest.12-0564

56. Long GL, Chandra T, Woo SL, Davie EW, Kurachi K. Complete sequence of the cDNA for human alpha 1-antitrypsin and the gene for the S variant. Biochemistry. 1984;23(21):4828-4837. doi: https://doi.org/10.1021/bi00316a003

57. Ogushi F, Hubbard RC, Fells GA, et al. Evaluation of the S-type of alpha-1-antitrypsin as an in vivo and in vitro inhibitor of neutrophil elastase. Am Rev Respir Dis. 1988;137(2):364-370. doi: https://doi.org/10.1164/ajrccm/137.2.364

58. Owen MC, Carrell RW, Brennan SO. The abnormality of the S variant of human alpha-1-antitrypsin. Biochim Biophys Acta. 1976;453:257-261.

doi: https://doi.org/10.1016/0005-2795(76)90271-3

59. Yoshida A, Ewing C, Wessels M, Lieberman J, Gaidulis L. Molecular abnormality of PI S variant of human alpha1antitrypsin. Am J Hum Genet. 1977;29:233-239.

60. Sandford AJ, Weir TD, Spinelli JJ, Pare PD. Z and S mutations of the alpha1-antitrypsin gene and the risk of chronic obstructive pulmonary disease. Am J Respir Cell Mol Biol. 1999;20(2):287291. doi: https://doi.org/10.1165/ajrcmb.20.2.3177
61. Chiuchiolo MJ, Crystal RG. Gene therapy for alpha-1 antitrypsin deficiency lung disease. Ann Am Thorac Soc. 2016;13(Suppl 4):S352-S369.

doi: https://doi.org/10.1513/AnnalsATS.201506-344KV

62. Gadek JE, Klein HG, Holland PV, Crystal RG. Replacement therapy of alpha 1-antitrypsin deficiency. Reversal of proteaseantiprotease imbalance within the alveolar structures of PiZ subjects. J Clin Invest. 1981;68:1158-1165. doi: https://doi.org/10.1172/JCI110360

63. Wewers MD, Casolaro MA, Sellers SE, et al. Replacement therapy for alpha 1-antitrypsin deficiency associated with emphysema. N Engl J Med. 1987;316:055-1062. doi: https://doi.org/10.1056/NEJM198704233161704

64. Chapman KR, Burdon JG, Piitulainen E, et al. Intravenous augmentation treatment and lung density in severe alpha1 antitrypsin deficiency (RAPID):a randomised, double-blind, placebo-controlled trial. Lancet. 2015;386(9991):360-368. doi: https://doi.org/10.1016/S0140-6736(15)60860-1

65. McElvaney NG, Burdon J, Holmes M, et al for the Rapid Extension Trial Group. Long-term efficacy and safety of alpha1 proteinase inhibitor treatment for emphysema caused by severe alpha1 antitrypsin deficiency:an open-label extension trial (RAPID-OLE). Lancet Respir Med. 2017;5:51-60.

66. American Thoracic Society/European Respiratory Society statement:standards for the diagnosis and management of individuals with alpha- 1 antitrypsin deficiency. Am J Respir Crit Care Med. 2003;168.(7):818-900. doi: https://doi.org/10.1164/rccm.168.7.818

67. Kaplan A, Cosentino L. Alpha1-antitrypsin deficiency:forgotten etiology. Can Fam Physician. 2010;56:19-24.

68. Thompson Healthcare. Red Book:Pharmacy's fundamental reference. Thomson Reuters:New York, NY; 2010.

69. Sondhi D, Stiles KM, De BP, Crystal RG. Genetic modification of the lung directed toward treatment of human disease. Hum Gene Ther. 2017;28(1):3-84. doi: https://doi.org/10.1089/hum.2016.152

70. Daya S, Berns KI. Gene therapy using adeno-associated virus vectors. Clin Microbiol Rev. 2008;21(4):583-593.

71. Manno CS, Pierce GF, Arruda VR, et al. Successful transduction of liver in hemophilia by AAV-Factor IX and limitations imposed by the host immune response. Nat Med. 2006;12:342-347. doi: https://doi.org/10.1038/nm1358

72. Gao G, Vandenberghe LH, Alvira MR, et al. Clades of adenoassociated viruses are widely disseminated in human tissues. $J$ Virol. 2004;78(12):6381-6388. doi: https://doi.org/10.1128/JVI.78.12.6381-6388.2004

73. Gao G, Vandenberghe LH, Wilson JM. New recombinant serotypes of AAV vectors. Curr Gene Ther. 2005;5(3):285-297. doi: https://doi.org/10.2174/1566523054065057 
74. Chiuchiolo MJ, Kaminsky SM, Sondhi D, et al. Intrapleural administration of an AAVrh.10 vector coding for human alpha 1antitrypsin for the treatment of alpha1-antitrypsin deficiency. Hum Gene Ther Clin Dev. 2013;24(4):161-173.

doi: https://doi.org/10.1089/humc.2013.168

75. Chulay JD, Ye GJ, Thomas DL, et al. Preclinical evaluation of a recombinant adeno-associated virus vector expressing human alpha-1 antitrypsin made using a recombinant herpes simplex virus production method. Hum Gene Ther. 2011;22(2):155-165. doi: https://doi.org/10.1089/hum.2010.118

76. Conlon TJ, Cossette T, Erger K, et al. Efficient hepatic delivery and expression from a recombinant adeno-associated virus 8 pseudotyped alpha 1-antitrypsin vector. Mol Ther. 2005;12(5):867875. doi: https://doi.org/10.1016/j.ymthe.2005.05.016

77. De B, Heguy A, Leopold PL, et al. Intrapleural administration of a serotype 5 adeno-associated virus coding for alpha1antitrypsin mediates persistent, high lung and serum levels of alpha1-antitrypsin. Mol Ther. 2004;10(6):1003-1010. doi: https://doi.org/10.1016/j.ymthe.2004.08.022

78. De BP, Heguy A, Hackett NR, et al. High levels of persistent expression of alpha1-antitrypsin mediated by the nonhuman primate serotype rh.10 adeno-associated virus despite preexisting immunity to common human adeno-associated viruses. Mol Ther. 2006;13(1):67-76. doi: https://doi.org/10.1016/j.ymthe.2005.09.003

79. Flotte TR, Conlon TJ, Poirier A, Campbell-Thompson M, Byrne BJ. Preclinical characterization of a recombinant adenoassociated virus type 1-pseudotyped vector demonstrates dosedependent injection site inflammation and dissemination of vector genomes to distant sites. Hum Gene Ther. 2007;18(3):245256. doi: https://doi.org/10.1089/hum.2006.113

80. Halbert CL, Madtes DK, Vaughan AE, et al. Expression of human alpha1-antitrypsin in mice and dogs following AAV6 vectormediated gene transfer to the lungs. Mol Ther. 2010;18(6):11651172. doi: https://doi.org/10.1038/mt.2010.51

81. Limberis MP, Wilson JM. Adeno-associated virus serotype 9 vectors transduce murine alveolar and nasal epithelia and can be readministered. Proc Natl Acad Sci USA. 2006;103(35):1299312998. doi: https://doi.org/10.1073/pnas.0601433103

82. Limberis MP, Vandenberghe LH, Zhang L, Pickles RJ, Wilson JM. Transduction efficiencies of novel AAV vectors in mouse airway epithelium in vivo and human ciliated airway epithelium in vitro. Mol Ther. 2009;17(2):294-301. doi: https://doi.org/10.1038/mt.2008.261

83. Liqun Wang R, McLaughlin T, Cossette T, et al. Recombinant AAV serotype and capsid mutant comparison for pulmonary gene transfer of alpha-1-antitrypsin using invasive and noninvasive delivery. Mol Ther. 2009;17(1):81-87.

doi: https://doi.org/10.1038/mt.2008.217
84. Lu Y, Choi YK, Campbell-Thompson M, et al. Therapeutic level of functional human alpha 1 antitrypsin (hAAT) secreted from murine muscle transduced by adeno-associated virus (rAAV1) vector. J Gene Med. 2006;8(6):730-735.

doi: https://doi.org/10.1002/jgm.896

85. Song S, Embury J, Laipis PJ, Berns KI, Crawford JM, Flotte TR. Stable therapeutic serum levels of human alpha-1 antitrypsin (AAT) after portal vein injection of recombinant adenoassociated virus (rAAV) vectors. Gene Ther. 2001;8:1299-1306. doi: https://doi.org/10.1038/sj.gt.3301422

86. Virella-Lowell I, Zusman B, Foust K, et al. Enhancing rAAV vector expression in the lung. $J$ Gene Med. 2005;7(7):842-850. doi: https://doi.org/10.1002/jgm.759

87. Xiao W, Berta SC, Lu MM, Moscioni AD, Tazelaar J, Wilson JM. Adeno-associated virus as a vector for liver-directed gene therapy. J Virol. 1998;72:10222-10226.

88. Yu H, Buff SM, Baatz JE, Virella-Lowell I. Oral instillation with surfactant phospholipid:a reliable alternative to intratracheal injection in mouse studies. Lab Anim. 2008;42(3):294-304. doi: https://doi.org/10.1258/la.2007.007055

89. Brantly ML, Chulay JD, Wang L, et al. Sustained transgene expression despite $\mathrm{T}$ lymphocyte responses in a clinical trial of rAAV1-AAT gene therapy. Proc Natl Acad Sci USA. 2009; 106(38):16363-16368.

doi: https://doi.org/10.1073/pnas.0904514106

90. Flotte TR, Trapnell BC, Humphries M, et al. Phase 2 clinical trial of a recombinant adeno-associated viral vector expressing alpha1-antitrypsin:interim results. Hum Gene Ther. 2011; 22(10):1239-1247. doi: https://doi.org/10.1089/hum.2011.053

91. Mueller C, Gernoux G, Gruntman AM, et al. 5 Year expression and neutrophil $\mathrm{D}=$ defect repair after gene therapy in alpha-1 antitrypsin aeficiency. Mol Ther. 2017;25(6):1387-1394. doi: https://doi.org/10.1016/j.ymthe.2017.03.029

92. Duan D, Yue Y, Yan Z, McCray PB, Jr., Engelhardt JF. Polarity influences the efficiency of recombinant adenoassociated virus infection in differentiated airway epithelia. Hum Gene Ther. 1998;9(18):2761-2776.

doi: https://doi.org/10.1089/hum.1998.9.18-2761

93. Bals R, Xiao W, Sang N, Weiner DJ, Meegalla RL, Wilson JM. Transduction of well-differentiated airway epithelium by recombinant adeno-associated virus is limited by vector entry. J Virol. 1999;73:6085-6088.

94. Ferrari S, Griesenbach U, Geddes DM, Alton E. Immunological hurdles to lung gene therapy. Clin Exp Immunol. 2003;132(1):1-8. doi: https://doi.org/10.1046/j.1365-2249.2003.02124.x

95. Pickles RJ. Physical and biological barriers to viral vectormediated delivery of genes to the airway epithelium. Proc Am Thorac Soc. 2004; 1(4):302-308.

doi: https://doi.org/10.1513/pats.200403-024MS 
96. Yang Y, Li Q, Ertl HC, Wilson JM. Cellular and humoral immune responses to viral antigens create barriers to lung-directed gene therapy with recombinant adenoviruses. J Virol. 1995;69:20042015.

97. Song S, Morgan M, Ellis T, et al. Sustained secretion of human alpha-1-antitrypsin from murine muscle transduced with adeno-associated virus vectors. Proc Natl Acad Sci USA. 1998; 95(24):14384-14388.

doi: https://doi.org/10.1073/pnas.95.24.14384

98. Brantly ML, Spencer LT, Humphries M, et al. Phase I trial of intramuscular injection of a recombinant adeno-associated virus serotype 2 alpha-1-antitrypsin (AAT) vector in AAT-deficient adults. Hum Gene Ther. 2006;17(12):1177-1186. doi: https://doi.org/10.1089/hum.2006.17.1177

99. Finley DJ, Rusch VW. Anatomy of the pleura. Thorac Surg Clin. 2011;21(2):157-163. doi: https://doi.org/10.1016/j.thorsurg.2010.12.001

100. Wang NS. Anatomy and physiology of the pleural space. Clin Chest Med. 6:3-16.

101. Agostoni E, Zocchi L. Pleural liquid and its exchanges. Respir Physiol Neurobiol. 2007;159(3):311-323. doi: https://doi.org/10.1016/j.resp.2007.07.002

102. Mutsaers SE. Mesothelial cells:their structure, function and role in serosal repair. Respirology. 2002;7(3):171-191. doi: https://doi.org/10.1046/j.1440-1843.2002.00404.x

103. Noppen M, De Waele M, Li R, et al. Volume and cellular content of normal pleural fluid in humans examined by pleural lavage. Am J Respir Crit Care Med. 2000;162(3):1023-1026. doi: https://doi.org/10.1164/ajrccm.162.3.9910050

104. Noppen M. Normal volume and cellular contents of pleural fluid. Curr Opin Pulm Med. 2001;7(4):180-182. doi: https://doi.org/10.1097/00063198-200107000-00002

105. Rennard SI, Jaurand MC, Bignon J, et al. Role of pleural mesothelial cells in the production of the submesothelial connective tissue matrix of lung. Am Rev Respir Dis. 1984;130:267-274.

106. Negrini D, Moriondo A. Pleural function and lymphatics. Acta Physiol (Oxf). 2013; 207(2):244-259.

doi: https://doi.org/10.1111/apha.12016

107. Boutin S, Monteilhet V, Veron P, et al. Prevalence of serum IgG and neutralizing factors against adeno-associated virus (AAV) types 1, 2, 5, 6, 8, and 9 in the healthy population:implications for gene therapy using AAV vectors. Hum Gene Ther. 2010;21(6):704-712. doi: https://doi.org/10.1089/hum.2009.182
108. Chiuchiolo MJ, Kaminsky SM, Sondhi D, Mancenido D, Hollmann C, Crystal RG. Phase I/II study of intrapleural administration of a serotype rh.10 replication-deficient adenoassociated virus gene transfer vector expressing the human alpha1-antitrypsin cDNA to individuals with alpha1-antitrypsin deficiency. Hum Gene Ther Clin Dev. 2014; 25(3):112-133. doi: https://doi.org/10.1089/humc.2014.2513 